\title{
"Na Grande Pátria, Nossa Tão Amada, o Culto que lhe Devemos"1: o Ensino de História no Grupo Escolar Barão de Mipibu - RN (1909-1920)
}

\author{
"In The Great Motherland, Our So Beloved, The Worship We Owe Them": \\ History Teaching At The School Group Of Barão De Mipibu - Rn (1909-1920) \\ "En La Gran Patria, Nuestra Tan Amada, El Culto Que Le Debemos": \\ La Enseñanza De Historia En El Grupo Escolar Barão De Mipibu - Rn (1909-1920).
}

Paula LoRena C. Albano da CRUZ²; Maria Inês S. Stamatto 3

\section{Resumo}

O presente trabalho tem por objeto de pesquisa o ensino de História no Grupo Escolar Barão de Mipibu - RN de 1909 a 1920. O seu objetivo é discutir como essa disciplina tornou-se elemento colaborador na formação do imaginário social republicano. As fontes analisadas na pesquisa foram Diários de Classe e o livro didático de História da instituição. O estudo se encontra inserido na História da Educação. Como aporte teórico foi utilizado as contribuições de Carvalho (1990) sobre a formação do imaginário social na República brasileira e Chervel (1990) acerca da História das disciplinas escolares. O trabalho possibilitou a compreensão da organização da disciplina História no Brasil ao longo dos tempos e de forma particular como via de contribuição da formação do cidadão brasileiro no início da República.

Palavras-chave: Ensino de História. Grupo Escolar. Imaginário.

\footnotetext{
${ }^{1}$ Trecho retirado do livro Nossa História de Rocha Pombo.

${ }^{2}$ Doutoranda em Educação (História da Educação) na Universidade Federal do Rio Grande do Norte. Bolsista Capes. E-mail: paulalcac@gmail.com

${ }^{3}$ Doutorado em História pela Université Sorbonne Nouvelle - Paris 3 (França), com estágio de pós-doutorado em Educação realizado na Université de Québéc, Montreal (Canadá). Professora Titular da Universidade Federal do Rio Grande do Norte. E-mail: stamattoines@gmail.com
} 


\begin{abstract}
This study has as research object the history teaching at the school group of Barão de Mipibu RN from 1909 to 1920. It aims to discuss about how that discipline has become a collaborator element in the formation of the republican social imaginary. The analyzed sources in the research were the classes diaries and the history textbook of the instituition. The study is inserted in the History of Education. As a theoretical framework was used Carvalho's (1990) contributions about the formation of social imaginary in the Brazilian Republic and Chervel (1990) about the history of school subjects. The work enabled the understanding of the organization of the discipline history in Brazil over time and especially as a way of contribution of the brazilian citizen formation in the beginning of the Republic.
\end{abstract}

Keywords: History teaching. School group. Imaginary.

\title{
Resumen
}

El presente trabajo tiene por objetivo de pesquisa la enseñanza de Historia en el Grupo Escolar Barão de Mipibu - RN de 1909 a 1920. Su objetivo es discutir como esa disciplina se ha tornado elemento colaborador en la formación del imaginario social republicano. Las fuentes analizadas en la pesquisa fueron los Diarios de Clase y el libro didáctico de Historia de la institución, bien como la legislación educacional local. El estudio se encuentra inserido en la Historia de la Educación. Como aporte teórico se utilizó las contribuciones de Carvalho (1990) sobre la formación del imaginario social na República brasileña y Chervel (1990) acerca de la Historia de las disciplinas escolares. El trabajo ha viabilizado la comprensión de la organización de la disciplina Historia en Brasil a lo largo de los tiempos y de forma particular como camino a la contribución para la formación del ciudadano brasileño en el inicio da República.

Palavras Clave: Enseñanza de Historia; Grupo Escolar; Imaginario 


\section{Introdução}

Os grupos escolares foram implantados no Brasil durante a Primeira República como um novo modelo de ensino primário, substituindo, paulatinamente, as escolas isoladas. A estrutura curricular era organizada por séries em faixa etária. Buscavam colocar em prática ideias acerca da educação, que vinham sendo discutidas desde a segunda metade do século XIX.

Para os republicanos a implantação dos grupos escolares tornou-se símbolo do progresso, em que a educação era vista como a redentora de todos os males sociais do Brasil, sendo implantada na maioria dos Estados, mas se concentrando apenas em cidades populosas.

O Grupo Escolar Barão de Mipibu, localizado na cidade de São José de Mipibu - RN, em uma região marcada pela elite canavieira do estado potiguar, foi criado em 1909 através do Decreto $\mathrm{n}^{\circ}$ 204, de 12 de Agosto de 1909 (RIO GRANDE DO NORTE, 1909, p. 83). O referido Grupo foi implantado seguindo as diretrizes dos grupos escolares do Rio Grande do Norte, que direcionavam as ações pedagógicas, os modos de agir dentro da escola, as disciplinas escolares e conteúdos ofertados aos alunos.

Entende-se que a preocupação com a criação de diretrizes se apresentavam como busca de difundir os valores e ideias republicanos, o que era evidenciado nas disciplinas escolares de forma mais latente, particularmente na de História Pátria.

Segundo Chervel (1990), as disciplinas escolares, termo que surgiu no século XX, vinculado às matérias escolares, aos conteúdos ensinados na escola, apresentam finalidades que trazem em si interesses, os quais podem se apresentar como "Finalidades mais sutis, de socialização do indivíduo no sentido amplo, da aprendizagem da disciplina social, da ordem, do silêncio, da higiene, da polidez, dos comportamentos decentes, etc" (1990, p.188).

Compreende-se que os grupos escolares, através das suas disciplinas escolares e particularmente a História Pátria, possuíam entre as suas finalidades, a sutil de buscar formar o espírito cívico dos alunos, de moldar o cidadão republicano, ou seja, inseri-lo na disciplina social, da ordem desejada pelos que promoviam os valores da República, para isso ofereciam o ensino de história como meio de construção do imaginário republicano. Pois como nos afirma Carvalho (1990, p. 10-11):

A elaboração de um imaginário é parte integrante da legitimação de qualquer regime político. É por meio do imaginário que se podem atingir não só a cabeça mas, de modo especial, o coração, isto é, as aspirações, os medos e as esperanças de um povo [...] a manipulação do imaginário social é particularmente importante em momentos de mudança político e social, em momentos de redefinição de identidades coletivas.

Era nesse contexto de mudança que o Brasil se encontrava e para se firmar o novo modelo político fez-se necessário construir um imaginário social pautado nos interesses republicanos, para isso, a História Pátria entra em cena na busca de alcançar e formar no espírito dos mais jovens o civismo. 


\section{História do ensino de História}

Ao pensar sobre a história do ensino de História no Brasil, pode-se dividi-la em dois momentos. Um concebido na colônia, onde é possível encontrar o saber histórico atrelado a disciplinas que se faziam presentes no currículo da época, sem autonomia, mas diluída em meio aos conteúdos estudados. Outro, a partir do Império, quando foi sendo organizada como disciplina escolar autônoma, com a presença de objetivos e métodos pedagógicos próprios.

No primeiro momento, durante o período colonial, o ensino foi marcado pela presença dos padres jesuítas, que atuavam no doutrinamento dos índios, na formação sacerdotal e no ensino dos filhos dos colonos. Aos últimos, era oferecida educação humanística, a qual possibilitava ingressos nas universidades portuguesas.

A Ratio Studiorium, orientava os Cursos de Humanidades, que ofereciam disciplinas como Retórica, Teologia e Filosofia e nas quais podiam-se encontrar o conteúdo histórico, diluído nos textos clássicos, ou seja, greco-romano e os de origem cristã.

Após a expulsão da Companhia de Jesus, no século XVIII pelo Marquês de Pombal, ministro do Estado português, houve uma reforma educacional no âmbito do ensino secundário, que transformou os Cursos de Humanidades em um sistema de Aulas Avulsas. Com essa mudança, o Marquês objetivava formar súditos que servissem aos interesses da Coroa portuguesa e não mais fosse dada a ênfase na formação de clérigos.

As mudanças ocorridas na educação desse período estavam imbuídas de ideais do liberalismo que em Portugal começava-se a abraçar, da preocupação de modernizar a máquina estatal portuguesa que se encontrava bem atrasada em comparação com os demais países europeus, bem como pelo interesse de diminuir a presença dos jesuítas não só na educação, mas em todas as realidades sociais, políticas e econômicas, pois alegava-se que a Companhia de Jesus estava enriquecendo à custas da Coroa. Outro fator que também contribuiu para a expulsão foi por desentendimentos entre colonos e padres, pois aqueles exigiam o uso compulsório da mão de obra indígena, alegando os altos custos do escravo negro e os jesuítas que se mostravam contra essa prática em relação aos índios.

Além de deixar de ser ensinado pelos jesuítas, Albano e Stamatto (2008, p. 2), nos apresentam outras mudanças no ensino através da implantação das Aulas Avulsas:

passaram a ser ministradas pelos professores em suas casas e não mais em seminários e colégios. As aulas eram autônomas, isoladas e os alunos podiam frequentar só uma cadeira por vez dependendo das existentes no local.

Essa dinâmica de frequentar uma cadeira por vez ocorria por causa da escassez de professores, pois era comum não haver todas as aulas em todos os locais, concentrando-se apenas nas principais vilas, tornando difícil e demorado o término de todas as cadeiras, ou seja, do curso completo (ALBANO e STAMATTO, 2008).

As aulas avulsas que começaram a ser ministradas nesse período e nas quais se encontram o saber histórico eram a Gramática Latina e Grega, Hebraico, Retórica e Filosofia. A História ensinada neste período, não era uma disciplina autônoma, mas possuir o saber histórico contido nos componentes acima, revelava sua importância, pois eram conhecimentos necessários para o acesso aos Estudos Maiores, sendo mais explicita na cadeira de línguas clássicas, a saber, a grega e latina, conforme explicita Toledo (2004, p. 37): 
a história estava entre as letras antigas através do estudo de erudição e obras de autores latinos e gregos [...] a história consistia, assim, em uma referência moral e religiosa para orientar os espíritos de noção sobre o passado da Grécia e Roma através de cursos de explicações de Cornelius Nepos, Cícero, Tito Lívio Salústio, Tácito, Tucídides, Demóstenes, Platão, Xenophon e outros autores gregos e latinos.

Durante a presença de D. João VI no Brasil, não houve mudanças significativas no que se refere ao ensino primário e secundário. A estrutura continuou a mesma que a da administração de Pombal, aumentando apenas a quantidade de cadeiras pelo reino. Já para o ensino profissionalizante e superior foram criados cursos de cunho profissional e alguns cursos e faculdades no ensino superior. A respeito da História, essa permaneceu incluída em outras disciplinas, somente em Vila Rica, Minas Gerais foi criada uma cadeira específica de História atrelada ao curso de Desenho com o objetivo de auxiliar na aprendizagem e desenvolvimento das artes (BRASIL, 1890).

A partir do período imperial houve uma preocupação com a sistematização do saber histórico, transformando-a em uma disciplina independente. O ensino de História, aparecia no currículo escolar, possuindo divisões, a saber: História Sagrada, História Universal e História Pátria (FONSECA, 2004). Essa tríade de conteúdo compuseram o ensino de História durante todo o Império. No entanto, não eram oferecidas concomitantemente, mas em momentos ou níveis diferentes.

Essa divisão da disciplina revela a importância dessas temáticas na época. A história Universal, ou seja, a das civilizações antigas e da Europa, as quais ditavam o desenvolvimento das demais nações, a partir delas as outras seriam construídas. A História Sagrada, a qual transmitiria os conhecimentos bíblicos e doutrinários através de textos e autores ligados a religião católica, que tinha seu espaço na disciplina por influência da Igreja Católica, a oficial do Império.

Por fim, a História Pátria, tão necessária a uma nação que estava começando a surgir como o Império brasileiro, entendia-se que deveria colaborar na formação do nacionalismo. A intenção de formar no povo uma consciência nacional era algo fundamental para o jovem Império. O ensino da "História Pátria" ao ser criado nesse contexto, objetivava formar uma identidade nacional.

Diante dessa preocupação o governo imperial passou a investir em estudos que se ocupassem com a construção de uma História Pátria pautada no nacionalismo. Um dos meios foi através da criação, em 1838, do IHGB - Instituto Histórico e Geográfico Brasileiro, que tinha como "sua missão de elaborar uma história nacional e de difundi-la por meio da educação, mais precisamente por meio do ensino de história" (FONSECA, 2004, p. 46).

Nesse período, uma das ações do IHGB foi propor um concurso para a elaboração da História Nacional. Um dos colaboradores para a escrita da nossa história foi Francisco Adolfo Varnhagen, sendo atribuído a ele o mérito de ser um dos maiores difusores da ideia de unificação nacional, que o Brasil necessitava tanto, já que era uma nação de proporções continentais e com uma diversidade étnica e regional considerável. 
Contudo, isso não foi um empecilho para a construção histórica pretendida por Varnhagen, pois "acreditava na existência de uma nação brasileira. A nação para ele era algo constituído por homens livres de uma única raça (brancos, é claro), agindo como cidadão" (PINSKY, 2004, p.14). Porém, a busca pela construção homogênea da História Pátria feita pelo estudioso, não levou em consideração as diversidades existentes no país, passando assim por cima dos conflitos regionais e étnicos, bem como das suas singularidades dentro da nação.

o passado aparece, portanto, de maneira a homogeneizar e a unificar as ações humanas na constituição de uma cultura nacional. A História se apresenta, assim, como uma das disciplinas fundamentais no processo de formação de uma identidade comum - o cidadão nacional - destinado a continuar a obra de organização da nação brasileira. (NADAI, 2004, p. 5).

Contudo, a versão histórica de homogeneização criada para a nação brasileira privilegiava apenas a elite, pois a existência do índio e do negro era marginalizada, apresentando-se de forma secundária. A “institucionalização de uma memória oficial, na qual as memórias dos grupos sociais, das etnias não dominantes economicamente, não se encontravam suficientemente identificadas, expressas, representadas ou valorizadas (NADAI, 2004, p. 5).

É nesse contexto é que a disciplina de História foi ganhando espaço e importância no Império, na busca da construção da ideia de que a Nação se constituiu de uma forma homogênea com a colaboração de todos e sem divergências ou singularidades.

\section{A História ensinada na formação do imaginário republicano}

A disciplina História adentrou a República com essa função de colaborar na construção da identidade nacional. No entanto, essa função tomou outra conotação, pois o novo regime pretendia construir a História Nacional em que se pudesse justificar a opção pelo regime republicano e não mais pelo imperial, em que a sociedade se compreendesse como cidadã republicana e não mais súditos de um imperador.

A educação foi um dos meios escolhidos pelo novo regime para que fosse formada a mentalidade do povo em relação as ideias republicanas e o ensino de História, juntamente com as disciplina Moral e Cívica, e Hinos foram utilizadas nesse intuito, pois se entendia como um veículo importante na formação do novo cidadão republicano.

A partir da República, o ensino de História foi tomando um caráter cada vez mais Patriótico e laico. A separação do Estado com a Igreja Católica, na primeira constituição republicana, influenciou logo a educação que deixou de ter a obrigatoriedade do ensino religioso, tornando as escolas públicas laicas, e nesse âmbito a História também deixou de estar vinculada a História Sacra, não tendo mais permissão de ser ministrada nas escolas públicas.

Foi um período em que se tentou implantar os valores e ideias defendidos pela República, como o patriotismo, nacionalismo, o liberalismo, positivismo, higienismo e a eugenia. Era preciso formar nas novas gerações um imaginário em que essas ideias fossem enraizadas e para isso várias estratégias foram adotadas inclusive acentuar a importância da disciplina História Pátria. Na legislação educacional do Governo do Rio Grande do Norte de 1916, observa-se a importância atribuída a disciplina. 
Art. 52- a formação do sentimento cívico será feita, principalmente, por meio de explicações sumárias sobre a organização política do Brasil, do RN e dos municípios, o exercício dos direitos e deveres do cidadão brasileiro e referências a fatos capitais da História Pátria;

Art. 53 - a instrução cívica será dada por meio de leituras, biografias, narração de fatos notáveis e outros meios adequados (RIO GRANDE DO NORTE, 1916, p. 55).

Essa disciplina era a grande responsável por formar nos jovens o sentimento de pertencimento, de amor à Pátria e de construir um imaginário cheio de heróis, mitos e símbolos, sendo considerada "a legitimadora da tradição nacional, da cultura, das crenças, da arte, do território” (BITTENCOURT, 2004, p. 43).

A preocupação em perpetuar nos mais jovens os 'fatos notáveis' de 'pessoas notáveis' na História Pátria, na realidade pretendia formar, a partir da imagem de um passado glorioso a perspectiva de um mesmo futuro regido pelo progresso, pela presença de um cidadão incorporado ao projeto republicano.

No entanto, como mostrar um passado glorioso, com uma nação unida, sem fazer as pazes com o período imperial, tão combatido e distorcido pelo governo republicano? Para isso se fazia necessário "eliminar as arestas, conciliar-se com o passado monarquista" (CARVALHO, 1990, p. 70). Para construir a unidade nacional, para consolidar o seu governo e a construção de uma História em que o povo se encontrasse, se identificasse, não era possível permanecer com o discurso de negação do período imperial, então a estratégia utilizada pelos republicanos foi o retorno às raízes do passado imperial para assim construir um novo imaginário. Essa atitude é explicada por Castoriadis ao afirmar que:

Todo o simbolismo se edifica sobre as ruinas dos edifícios simbólicos precedentes, utilizando seus materiais - mesmo que seja só para preencher as fundações de novos templos (CASTORIADIS, 1982, p. 146).

Não era possível começar do nada, mas sim considerar a História já construída e enraizada na população. Portanto, fez-se necessário, estrategicamente, voltar-se ao passado imperial, pois para o povo já existiam heróis, mitos e símbolos que faziam parte do seu imaginário.

Segundo Carvalho (1990), a escolha dos mitos e heróis nacionais deu-se no entorno da tradição e não dos que teriam proclamado a República. Essa foi uma das estratégias encontradas pelos republicanos para garantir a aceitação do povo, pois:

[...] heróis são símbolos poderosos, encarnações de ideias e aspirações, pontos de referência, fulcros de identificação coletiva. São, por isso, instrumentos eficazes para atingir a cabeça e o coração dos cidadãos a serviço da legitimação de regimes políticos (CARVALHO,1990, p. 55).

Contudo, os republicanos esbarraram em duas situações que precisavam ser trabalhadas nesse processo de construção da História nacional e de aceitação do novo regime por parte da população, a saber: a falta de pertencimento por parte da sociedade ao sistema republicano, e um país heterogêneo, com várias culturas e etnias. 
A população desconhecia o sistema republicano e os ideais pretendidos pelos grupos que se instalaram no poder, o que dificultava a sua acolhida. $\mathrm{O}$ império ainda estava muito presente no imaginário do povo. O outro ponto, era o mesmo desafio enfrentado na construção da História Nacional no período imperial, explicar as diferenças regionais e étnicas brasileiras buscando mostrar uma unificação ao país através de uma história homogênea. Durante o Império, a decisão foi homogeneizar sem considerar as diferenças, na República também se persistiu na mesma escolha, porém com um fator novo que era a inclusão do negro como cidadão, antes visto como escravo, agora precisava ser explicado e incluído na história como um homem livre que era membro da nação.

No âmbito dos programas curriculares percebe-se como a disciplina História Pátria com seus conteúdos, métodos e materiais didáticos foi colaborando para se tentar buscar um envolvimento maior do povo na identificação com o governo.

\section{A criação dos heróis nacionais: o elo entre o povo e a República}

A ideia de desenvolver na população brasileira o sentimento de pertencimento ao regime republicano foi arquitetada através de um retorno ao passado em que se apresentasse os heróis já consagrados e a partir disso ir acrescentando os heróis da República. Por isso, pode-se entender o registro nos Diários de Classe do Grupo Escolar Barão de Mipibu, de aulas destinadas aos estudos de personagens que foram sendo caracterizados como homens responsáveis pela fundação, formação, libertação ou civilização do que ao longo da história foi se constituindo como Brasil. Os personagens que encontramos de forma mais recorrente foram: Cristovão Colombo, Pedro Álvares Cabral, Pero Vaz de Caminha, Caramuru, Ramalho, Anchieta, Frei Miguelinho, Tiradentes, D. Pedro II, José Bonifácio, Benjamin Constant e Deodoro Da Fonseca.

Esses personagens eram interpretados como homens que deram sua vida em prol da libertação do Brasil, da sua construção, do seu progresso, pois a ideia de nação estava atrelada a busca de personagens que personificassem heróis nacionais e que mesmo estando tão distantes no tempo, legitimassem o novo regime.

Contudo, em meio a tantos personagens era necessário um que possuísse o poder de gerar na população um sentimento de pertencimento. Nesse intuito, foi escolhido Tiradentes, personagem que viveu no período colonial, mas que desde o Império já se fazia presente no imaginário do povo e que fora entendido como o possível elo entre o povo e a República na busca da construção de uma identidade nacional, representando as ideias de liberdade e unidade nacional, nos quais o povo se sentisse representado (CARVALHO, 1990).

Assim os republicanos foram buscar em Tiradentes o seu Herói nacional, atrelando-o as ideias de nação, liberdade, coragem, unidade, para, além disso, um mártir, pois diante da religiosidade do povo, foi preciso agregar-lhe um viés religioso, um mártir da nação. A apropriação de um viés religioso, logo construiu a figura de Tiradentes com aspectos de um novo Cristo, o salvador da pátria, tornando-se um Herói cívico-religioso (CARVALHO, 1990).

O termo 'herói' sofreu várias mudanças ao longo dos tempos, Le Goff (2011) explica que na Antiguidade o herói se encontrava em um plano, que ia além da coragem natural do homem, porém não chegava a estar na categoria de um deus ou semi-deus. Na Idade Média a coragem passou a ter outra conotação ligada a religião, o herói passava a ser visto como o santo. Somente a partir do século XII foi que tornou-se um adjetivo seguido de substantivo, passando a ter o sentido de cortês, gentil, belo, franco. 
Ao observar a construção de Tiradentes como herói nacional percebe-se que os significados dados ao termo 'herói' ao longo dos séculos, ressoaram no entendimento das características do herói nacional brasileiro. A imagem de Tiradentes foi construída incluindo essas visões: de coragem - capaz de morrer pelos seus ideais; como também de santo, mártir o salvador da Pátria.

As imagens construídas pelos republicanos sobre Tiradentes buscavam formar o herói nacional no imaginário do povo, pois o lugar por excelência da formação de heróis, lendas e mitos está no imaginar, como nos afirma Miceli (1988, p. 41), "o habitat do herói é a imaginação, e cada um deve vê-lo (senti-lo) com seus próprios olhos”. É através da imaginação, do imaginário social que se pode alcançar o coração do povo, pois é a partir disso que é gerado o sentimento de pertencimento a algo.

Nesse processo de construção do herói, encontra-se algo relevante que é a aparência física do personagem. Le Goff (2011) explica através da construção da imagem de Carlos Magno, que nem sempre corresponde à realidade, mas o que prevalece no imaginário é a imagem que se forma do personagem.

Segundo o autor (2011), a imagem de Carlos Magno como herói e lenda medieval, teve grande contribuição de Eginhardo, autor de A vida de Carlos Magno (840). Esse descrevia Carlos Magno com a imagem de um homem da cabeça redonda, olhos grandes, nariz um pouco maior que a média com belos cabelos brancos e de expressão alegre. Na realidade, Eginhardo buscava mostrar Carlos Magno como um autêntico rei franco, mesmo que a sua origem fosse germânica.

A respeito de Tiradentes, a imagem que se construiu e perpetuou foi a de um novo Cristo. A impressão que se desejava deixar era de um mártir cívico, mesmo que esse em sua origem não tivesse nenhuma relação com a religião, mas pelo caráter religioso da população, atrelava-se elementos da cultura religiosa do povo e se incorporava ao seu ideal propagandista, gerando a unidade mística dos cidadãos (CARVALHO, 1990).

José Murilo de Carvalho, nos mostra na pintura de Pedro Américo, Tiradentes Esquartejado (1893), o quanto ela buscava imprimir nos observadores a imagem de um Tiradentes mártir, semelhante a Cristo e que deu a vida por amor a nação brasileira (1990). O personagem pertencente a colônia acabou se tornando o elo com a tradição e passou a ser visto como símbolo do republicanismo brasileiro, o herói que por amor a sua pátria ofertou a sua vida.

Os republicanos, após 1889, não alteraram substancialmente as diretrizes da produção historiográfica ou dos manuais didáticos. Mas operaram uma inversão significativa na abordagem dada à Inconfidência, elevada agora a condição de movimento-símbolo da luta republicana (FONSECA, 2004, p. 74).

Ao ser formado o mito do herói nacional, a República precisou disseminá-lo e para isso utilizou-se do ensino de história ministrado nas escolas:

A escola, auxiliada pela família, é um dos principais instrumentos destinados à perpetuação do herói. É lá que datas cívicas, festejos e comemorações - sem falar nas aulas - reforçam na memória das crianças a saga desses personagens especiais (MICELI, 1988, p. 18). 
Nos Diários de Classe do Grupo Escolar Barão de Mipibu, confirmam-se a afirmativa de Miceli, pois há inúmeros momentos dedicados a esse assunto nas aulas de História. No Grupo dedicavam-se ao estudo de diversos personagens, além de Tiradentes, como Pedro Álvares Cabral, Pero Vaz de Caminha, Caramuru, Ramalho, Anchieta, os Governadores Gerais, Frei Miguelinho e Tiradentes, D. Pedro II, José Bonifácio, entre outros. A prática de cultuar personagens históricos revela que a tradição vinda do Império na produção da História nacional continuou na República, pois já se encontrava inserida no imaginário do povo, atrelando apenas os heróis republicanos como Deodoro da Fonseca e Benjamin Constant.

A exemplo da construção dos heróis nacionais, no Rio Grande do Norte também procurou-se construir os heróis locais. No Grupo Escolar Barão de Mipibu, dentro das aulas de História Pátria foram dedicados momentos para o estudo da História Local como foi orientado pelo Regimento Interno em 1913 (MEDEIROS, 2004) e, a qual seguia os mesmos direcionamentos da História Pátria, fixando a atenção a biografia de homens que eram considerados os responsáveis pela formação do Estado do Rio Grande do Norte como André de Albuquerque, Felipe Camarão e os fundadores do RN, e bem como eventos como a Revolução de 1817, ressaltando o viés republicano do evento. Essa preocupação em ensinar os fatos e heróis locais, tinha o mesmo intuito da História nacional, sendo translada no âmbito local.

Portanto, Tiradentes e tantos outros personagens foram sendo colocados como heróis da Pátria e do Rio Grande do Norte, para assim construir-se um imaginário coletivo de uma nação repleta de sujeitos que dedicaram a suas vidas por amor à Nação e da utilização de uma disciplina na busca de disseminar essas imagens.

\section{Unidade nacional: 'somos todos iguais'.}

A outra situação que encontrou-se na República e que precisava ser explicada foi a constituição do povo brasileiro, que naquele momento precisava incluir os negros à sociedade brasileira como cidadãos e não mais escravos. Um país marcado pela variedade de etnias e de regiões necessitava de uma história que o unisse, para que assim conseguisse gerar o sentimento de pertencimento.

No ensino de História as etnias precisavam ser apresentadas através de funções desempenhadas na sociedade brasileira, mas que estavam ligadas a soberania branca, o qual era responsável por auxiliar as demais etnias:

Ao branco, cabia representar o papel do civilizador. Ao índio, era necessário restituir sua dignidade original, ajudando-o a galgar os degraus da civilização. Ao negro, por fim, restava o espaço de detração, mas uma vez que era entendido como fator de impedimento ao progresso da nação (SCHWARCZ, 1993, p.21).

$\mathrm{Na}$ análise feita nos Diários de Classe do Grupo Escolar em estudo, os brancos apareciam constantemente nos conteúdos de História, e colocados como agentes civilizadores, aqueles que levaram ao país o progresso, a civilização consumindo as suas próprias vidas pelo Brasil e por isso eram apresentados como heróis nacionais. Em muitos momentos observou-se estudos dedicados aos colonizadores, os "homens bons" da elite em geral. 
Em outros momentos nos Diários de classe, o personagem indígena era estudado junto com os heróis brancos em temas de aulas como: Descoberta do Brasil - Cabral e os índios; Os costumes dos índios - Padre Anchieta; Os índios e os colonos; Caramuru e Ramalho; e Homem e o índio (GRUPO ESCOLAR BARÃO DE MIPIBU, 1918-1921). A respeito do estudo da cultura indígena encontrou-se somente um tema discriminado que foi "Costumes indígenas".

A respeito do homem negro, pôde-se inferir que o tema começou a ser trabalhado em sala de aula a partir de 1918, pois somente a partir desse ano é que foi identificada a temática expressa nos registros dos Diários de Classe. Os temas abordados eram poucos, sendo somente relacionados à abolição, e apresentando os assuntos como uma ação benévola de homens brancos como Joaquim Nabuco e José do Patrocínio, ou seja, a abolição veio pelas mãos dos brancos e não pelas lutas e resistências dos negros. Como também não foi encontrado em nenhum dos diários a inclusão da princesa Isabel dentro da temática, pois mesmo com toda a sua participação no processo de abolição da escravatura, sendo a responsável por assinar a lei Áurea, à mulher não encontrava lugar de destaque na história da pátria brasileira naquela época, o que nos revela que o ensino de História possuía caraterísticas de uma educação elitista, eugenista e machista.

Os costumes e a cultura dos negros, bem como a sua contribuição na formação do povo brasileiro ou ainda os desafios e lutas do povo africano não se apresentavam como assuntos importantes de serem levantados ou questionados, o interesse era amenizar ao máximo as diferenças para gerar a ideia de homogeneidade, de se criar uma imagem de democracia racial:

A miscigenação pesou enquanto fator homogeneizador da sociedade pósabolição, no início do século XX. O mulato e a mulata passam a ser símbolos de uma convivência com bases na tolerância, uma política pública que deu certo, a ponto de negar quaisquer tipos de injustiça e/ ou discriminação no Brasil por questões de cor (ALVES, 2007, P. 21).

Na formação da nação brasileira republicana não interessava a heterogeneidade ética ou cultural do país. A História deveria ser ensinada transmitindo a ideia de amor à pátria por meio dos seus heróis, de homogeneidade das etnias com o predomínio dos homens brancos como heróis nacionais.

\section{O livro didático: a linguagem imagética na construção da História Nacional.}

O livro didático se tornou um dos instrumentos de construção do imaginário republicano, pois era através dele que as crianças tinham contato, a partir das imagens, com o universo dos heróis e do seu feitos. Fazia parte do programa educacional do Governo republicano a elaboração de cartilhas e livros didáticos para o uso dos alunos e o Grupo Escolar Barão Mipibu, estava atento às novidades educacionais e os direcionamentos acerca do material didático, assim adotou um dos livros orientados para o ensino de História Pátria que fora recentemente lançado, a saber: Nossa História de Rocha Pombo ${ }^{4}$.

\footnotetext{
${ }^{4}$ Rocha pombo: Jornalista e historiador, fazia campanhas abolicionistas e republicanas. Foi membro do Instituto Histórico e Geográfico Brasileiro e escreveu vários livros de História além de Nossa Pátria, a saber, História da América, História do Rio Grande do Norte, História do Paraná.
} 
Os materiais didáticos revelam como chegava às crianças, a construção do que deveria ser ensinado na História e difundido como 'verdades'. O livro Nossa Pátria foi o único encontrado no Grupo Escolar com a temática sobre a História, sendo mencionado diversas vezes nos Diários de Classe. Foi lançada a sua $1^{a}$ edição em 1917, continha cerca de cento e cinquenta páginas e era dedicado ao público infantil com capítulos que não passavam de cinco páginas em geral, contendo uma leitura simples e objetiva, cercada por imagens.

É importante perceber que o livro de Rocha Pombo comungava com os ideais de sua época e, portanto, era uma obra apta e indicada ao ensino dos jovens do período, fomentando nesses o "amor à pátria", visto nitidamente em todo o livro, a começar pelo título do livro: Nossa Pátria; bem como pelas primeiras páginas, nas quais o autor descreve o significado de pátria:

Pátria! Terra de nossos pais; onde viveram nossos avós; onde temos todas as recordações da nossa vida e da nossa família; onde tudo nos fala a alma campos e mares, florestas e montanhas e onde parece que até as estrelas e os próprios ares nos alegram mais que os outros céus! E por isso mesmo que amamos a nossa pátria mais que as outra pátrias (POMBO, 1947, p. 1).

Essa construção da História e do amor à pátria era feita através das suas páginas ilustradas com imagens de símbolos, de heróis e de eventos apresentados como manifestação de toda a população.

Rocha Pombo construiu o seu livro dando ênfase a personagens como heróis e fatos, que na cultura da época se entendia como aspectos importantes e que ajudavam a forjar o imaginário da nação republicana, isso é percebido através de uma afirmação sua logo no início do livro quando escreve que "Sentir o que fizeram os nossos grandes antepassados equivale a tomar compromisso de os continuar na história" (POMBO, 1947, p.3). Bem como eventos, dos quais podemos citar o da Independência, no qual o autor apresenta como sendo algo desejado por toda a população e que teria sido o fato mais importante da História nacional, pois foi a partir disso que nos tornamos soberanos, donos de si mesmos e com uma bandeira e hino próprios da nação brasileira (POMBO, 1947).

Em relação a defesa do heroísmo, o autor apresenta vários personagens como colaboradores da formação da nação. No livro não havia uma preocupação em construir o herói, refletindo acerca dos seus atos, mas ele já estava posto, pronto, sendo apresentado as novas gerações como tal. A figura de Tiradentes, que teve a sua imagem discutida e apresentada como elo na construção da identidade nacional no início da República, aparece no livro de Rocha Pombo como um das mais importantes personalidades heroicas brasileira.

Este é um homem dos mais dignos entre os que figuram a nossa história como exemplos de amor à Pátria. Também, soube ele morrer com o seu silêncio, a sua coragem e a sua resignação cristã, aquela tirania que pesava sobre os povos da colônia como uma grande mão de ferro (POMBO, 1947, p. 90-91).

Contudo, mesmo se voltando para a tradição histórica brasileira, os republicanos também foram inserindo o evento da Proclamação da República, apresentando-a de forma grandiosa e necessária para o bem do país. Os Diários de classe do Grupo Escolar Barão de Mipibu revelam que em todas as séries estudavam esse assunto, sendo ele vinculado a personalidade de Benjamin Constant. 
A ênfase dada a esse personagem nas aulas, infere que, os republicanos buscaram transformá-lo em herói nacional da Proclamação da República, e isso deve-se pela influência positivista que a História sofreu nesse período.

Segundo Carvalho (1990), alegavam a importância de Benjamin Constant como um dos personagens que deveria ser lembrado com a qualificação de fundador da República, pois teria sido a cabeça pensante dessa, sem o qual o evento de 15 de novembro não teria passado de uma quartelada que teria derrubado o ministro Visconde de Ouro Preto.

Os republicanos buscaram colocar Benjamin Constant no panteão cívico brasileiro, ficando esse composto por "Tiradentes na Inconfidência, José Bonifácio na Independência, Benjamin na República, era essa, para os ortodoxos, a trindade cívica que representava o avanço da sociedade brasileira" (CARVALHO, 1990, p. 42).

A respeito da formação do povo brasileiro, o livro dedica um capítulo para negros e outro para índios. A respeito desses, era passado através do livro que o índio via com bons olhos a ideia de incorporação da superioridade europeia, como se esses fossem responsáveis por trazer a civilização aos povos ameríndios, os quais se encontravam na escuridão da ignorância. Vários trechos do livro, o autor enfatiza a ideia de selvagem e civilização como observa-se a seguir: "Estes [índios] ainda estavam muito atrasados quanto a civilização" (POMBO, 1947, p. 26); "entre uma nação e outra, quase sempre havia questões e briga. Por isso ficaram os índios, a final, muito dados a guerra. Entre selvagens isso era natural. Só o homem civilizado e que confia mais na razão que na força, e resolve tudo pelo direito e não pelas armas” (POMBO, 1947, p. 30).

Além dos trechos acima, percebe-se a tentativa de mostrar que o processo de enculturação foi passivo, contando com a colaboração dos índios que entendiam isso como algo aceitável.

Ao lugar do desembarque deu Cabral o nome de Porto Seguro; e celebrou-se ali a cerimônia que foi muito festiva e tocante. Ergue-se na praia uma grande cruz de madeira e, junto a ela, um altar onde se cantou a primeira missa em terra da nossa América. Diante de tudo aquilo, os índios mostraram-se muito espantados, imitando os portugueses em tudo o que estes faziam. Houve um velho, entre os índios, que no seu espanto apontava para o alto da cruz, como sentindo-se arrebatado de alegria à vista daquele estranho sinal que lhe falava ao coração (POMBO, 1947, p. 22).

Sobre os negros, o capítulo trata de buscar amenizar a violência da escravidão, justificando-a que os negros já viviam em escravidão na África, vendidos pelos próprios pares, portanto os negros agiram de forma passiva ao trabalho compulsório feito pelos portugueses, pois já estavam acostumados àquela realidade e os que fugiam era porque alguns senhores de escravos os maltratavam. Contudo, segundo o autor, a maioria era feliz nessa condição.

Quase todos, em vez de odiar, ficaram logo querendo bem aos seus senhores. Sobretudo as mulheres foram grandes amigas das crianças [...] sofreram bastante saindo lá do meio dos seus; e as vezes o sacrifício para eles era tão grande que chegavam a morrer de saudade. Afinal a raça foi recompensada, pois os descendentes daqueles pobres escravos hoje são iguais ao antigos senhores, e sem dúvida muito mais felizes do que os parentes que ficaram lá na África [...] hoje somos todos como irmãos (POMBO, 1947, p. 33). 
Ao tratar do sofrimento vivido pelos escravos, em nenhum momento, Rocha Pombo se refere as torturas, maus tratos, as condições sub-humanas vividas pelos negros, apresentando a causa do sofrer dos africanos devido apenas a saudade dos seus. Bem como tenta mostrar que após a abolição, os ex-escravos passaram a ser visto de forma igual aos brancos, sem considerar os preconceitos raciais existentes na sociedade brasileira, como também as condições econômicas e sociais oferecidas aos libertos que os deixaram a margem da sociedade brasileira. Isso, porque a intenção era construir uma imagem de um país igualitário, homogêneo e que vivia em paz.

Além da construção de uma sociedade sem diferenças e desigualdades, o autor ainda busca justificar o trabalho compulsório através de elogios aos negros e apresentando a importância desse povo como colaborador para o crescimento da economia do país: "trabalhadores obedientes e muito espertos, os Africanos fizeram muito pelo progresso do nosso país” (POMBO, 1947, p. 35).

Mesmo ao se tratar da Abolição da escravatura, essa era vista como uma ação louvável de pessoas de origem étnica branca e pertencentes a elite como Eusébio de Queiroz, Visconde de Rio Branco, Joaquim Nabuco, José do Patrocínio e a princesa Isabel. O livro ao tratar da abolição mostra a imagem de cada um desses, reforçando no imaginário das crianças uma história repleta de 'homens bons', heróis brancos e pertencentes a elite. Não foi observado na apresentação da abolição, a inclusão de fatores importantes que culminaram nesse evento como a resistência dos escravos, as pressões internacionais ou os desafios econômicos, mas a justificativa que tal prática foi realizada por quase todos os países das Américas e Europa.

Portanto, o que o livro de Rocha Pombo e toda política de construção da formação do povo brasileiro buscavam era reforçar nas novas gerações que se formavam naquele período a imagem de que viveram todos em igualdade, não sendo mencionadas as diferenças sociais ou jurídicas entre as etnias, porém o homem branco fora o grande responsável pelo desenvolvimento e civilização do povo do Brasil.

O livro didático de História tinha a responsabilidade de construir essa imagem de um país unido, mesmo com tantas diversidades étnicas. Aos alunos era imposto que aprendessem, e se fosse necessário de cor, os fatos que se diziam importante para a nação. Ao trabalhar a descrição minuciosa dos fatos, os alunos precisavam memorizar os fatos que eram descritos pelo livro didático e isso conduzia a imaginação desses acerca do assunto. O contato com os textos e as imagens retratadas no livro contribuíam para a construção desse imaginário. A imagem que se tinha do evento era construída através dessas estratégias. O livro didático se transformava assim em agente colaborador na formação do imaginário social republicano.

\section{Considerações finais}

Ao estudar o ensino de História no Brasil durante o início do século XX, pode-se perceber como essa área do conhecimento foi se constituindo e se tornando o carro chefe na busca da formação do cidadão republicano, sendo utilizada para justificar as ideologias e o poder vigente. O objetivo do ensino de História no início da República era, através de um passado glorioso, formar uma sociedade republicana, que aderisse às ideias desse sistema político, contribuindo na formação do cidadão cívico, o qual amasse a pátria republicana, comungando com o ideário que se pretendia divulgar. Portanto, percebe-se a importância de 
toda a divulgação feita pelos republicanos através da Educação, para se concretizar a ideia de que o sistema republicano era melhor do que a monarquia para o país.

A necessidade de se estudar personagens, datas e eventos era justificada pela necessidade de se construir uma Nação brasileira, por mais que fosse preciso apresentar apenas as visões e interpretações que interessassem na construção da História Pátria, renegando a sua função de despertar e formar a criticidade em favor de outras propostas e interesses.

\section{Referências}

ALBANO, P. L. C.; STAMATTO, M. I. S. A história ensinada e as Aulas Régias na capitania do Rio Grande (1808 - 1821). Mneme: Revista de Humanidades. UFRN, Caicó/RN, v. 9. n. 24 , set/out. 2008. Disponível em: <http://www.cerescaico.ufrn.br/mneme/anais>. Acesso em 28 jun 2013.

ALVES, Roberta de Souza. Ensino de História e cultura afro-brasileira e africana: da lei ao cotidiano escolar. São Paulo: UNESP, 2007. Monografia. (Curso de Pedagogia). Disponível em: <http//:www.fc.unesp.br/upload/pedagogia/TCC\%20Roberta\%20-\%20Final.pdf> Acesso em: 15 ago 2013.

BITTENCOURT, Circe. As 'Tradições Nacionais" e o Ritual das Festas Cívicas. In: PINSIKY, Jaime. O ensino de História e a criação do fato. 11. ed. São Paulo: Contexto, 2004.

CARVALHO, José Murilo de. A formação das almas: o imaginário da República no Brasil. São Paulo: Companhia das Letras, 1990.

CASTORIADIS, Cornelius. A instituição imaginária da sociedade. 2. ed. Rio de Janeiro: Paz e Terra, 1982.

CHERVEL, André. História das disciplinas escolares: reflexões sobre um campo de pesquisa. Teoria \& Educação, n.2, p.177-229. 1990.

BRASIL. Coleção de leis do Brasil. (1817-1821). Rio de Janeiro: Imprensa, 1890.

FONSECA, Thaís Nívia de Lima e. História e ensino de História. 2. ed. Belo Horizonte: Autêntica, 2004.

LE GOFF, Jacques. Heróis e maravilhas da Idade Média. 2. ed. Petrópolis, RJ: Vozes, 2011.

MEDEIROS, Adriana Moreira Lins de. O ensino de história nos currículos escolares do Rio Grande do Norte. In: ENCONTRO NORDESTINO DE HISTÓRIA, 5 Anpuh. 2004. Acessado em 18/08/13 http://pe.anpuh.org/resources/pe/anais/encontro5/14-osdesafios/Artigo\%20de\% 20Adriana\%20Moreira\%20Lins\%20de\%20Medeiros.pdf

MICELI, Paulo. O mito do herói nacional. São Paulo: Contexto,1988. 
NADAI, Elza. O ensino de História e a "Pedagogia do Cidadão". In: PINSKY, Jaime. O ensino de História e a Criação do fato. 11 ed. São Paulo: Contexto, 2004.

PINSKY, Jaime. Nação e ensino de História no Brasil. In: O ensino de História e a criação do fato. 11 ed. São Paulo: Contexto, 2004.

SCHWARCZ, Lilia Moritz. O espetáculo das raças: cientistas e questão racial no Brasil (18701930). São Paulo: Companhia das Letras, 1993.

TOLEDO, A História ensinada sob o império da memória: questões de história da disciplina. Revista História, São Paulo: UNESP, v. 23, nº 1⁄2, 2004.

\section{Fontes}

GRUPO ESCOLAR BARÃO DE MIPIBU. Diários de classe da Escola feminina do Grupo Escolar Barão de Mipibu: 1918-1921. São José de Mipibu, 1921.

GRUPO ESCOLAR BARÃO DE MIPIBU. Diários de classe da Escola masculina do Grupo Escolar Barão de Mipibu: 1918-1921. São José de Mipibu, 1921.

POMBO, Rocha. Nossa Pátria: narração dos fatos do Brasil através da sua evolução. 81 ed. São Paulo: Melhoramentos, 1947.

RIO GRANDE DO NORTE. Decreto n 204, de 12 de Agosto de 1909. Cria o Grupo Escolar Barão de Mipibu em São José de Mipibu. In: Atos Legislativos e Decretos do Estado do Rio Grande do Norte. Natal: Tipografia de A República, 1909.

RIO GRANDE DO NORTE. Lei no 405 de 29 de novembro de 1916. Reorganiza o ensino primário, secundário e profissional no Estado. In: Atos Legislativos e Decretos do governo do Estado do Rio Grande do Norte. Natal: Typ. d'A República, 1916. 